\title{
REFORMULASI HUKUM PERCERAIAN DI PAKISTAN
}

\author{
Syaifuddin Zuhdi, S.HI.,M.HI \\ Universitas Muhammadiyah Surakarta \\ sz123@ums.ac.id
}

\begin{abstract}
Abstrak
$\neg$ Dujuan dari penulisan ini adalah untuk mengetahui reformulasi hukum keluarga di Negara Pakistan dan untuk mengetahui metode reformulasi hukum keluarga yang digunakan Negara tersebut. Metode yang digunakan adalah deskriptif analitis, jenis penelitian adalah studi kepustakaan, berdasarkan data yang digunakan, penelitian ini merupakan penelitian kualitatif. Temuan dari pembahasan ini adalah bahwa benih pembaharuan hukum keluarga yang ada di Pakistan telah ada semenjak masih dibawah penjajahan Inggris, dan metode yang digunakan adalah intra doctrinal reform serta ekstra doctrinal reform.

Kata kunci: Reformulasi, Hukum Keluarga, Perceraian, Pakistan

Abstract

7 he purpose of this paper is to determine how the reformulation of family law in Pakistan and to find out how the reformulation methods used by family law of that State. The method used in this research is descriptive analysis, this kind of research is the study of literature, based on the data used, this study is a qualitative research. The findings from this discussion is family law reform in Pakistan has began since colonized by British rule and the method used by the state are intra doctrinal reform and extra doctrinal reform.
\end{abstract}

Keywords: Reformulation, Family Law, Divorce, Pakistan

\section{PENDAHULUAN}

Pakistan yang mempunyai nama panjang Islami Jumhuriyya e-Pakistan (Islamic Republic of Pakistan), merupakan sebuah negara pecahan India yang secara geografis terbentang di Asia bagian selatan dengan luas wilayah mencapai $803.940 \mathrm{~km} 2 .{ }^{1}$ Pada tahun 2016 penduduk di negara ini tercatat berjumlah 201.275.591 jiwa dan mayoritas beragama Islam dengan prosentase sebesar $97 \%,{ }^{2}$ oleh karenanya Pakistan terdaftar sebagai negara dengan bangsa muslim terbesar kedua di dunia. ${ }^{3}$ Secara garis besar masyarakat muslim di Pakistan terbagi dalam dua golongan, yakni sunni dan syiah. Muslim sunni di Pakistan mayoritas merupakan pemeluk madzhab hanafi dan minoritas merupakan pengikut madzhab syafi'i serta hanbali. Adapun golongan syiah di negara ini mayoritas berasal dari golongan Itsna Asy'ariyah, sedangkan sebagian kecil lainnya merupakan golongan syiah Isma'iliyah. ${ }^{4}$

Sebelum Pakistan merdeka, madzhab hanafi telah tumbuh menjadi warna hukum kehidupan masyarakat muslim di India. Hal tersebut berlangsung beberapa dekade hingga tahun 1915

1 Badri Yatim, Ensiklopedia Islam, (Jakarta: Ichtiar Baru Van Hoeve,2004)hal 256. Menurut versi lain Pakistan hanya mempunyai luas wilayah $796.095 \mathrm{~km} 2$ karena ada dua wilayah yang masuk dalam perdebatan yakni Jammu dengan luas $11.639 \mathrm{~km} 2$ dan AzadKashmir dengan luas $72.520 \mathrm{~km} 2$, lihat Library of Congress-Federal Research divission : Pakistan, februari 2005

2 http://www.census.gov/popclock/world/pk diakses pada tanggal 28 september 2016

3 John L Esposito, The Oxford Encyclopedia of The Modern Muslim World, terj. Eva YN dkk, Ensiklopedia oxford : dunia Islam modern. (Bandung : Mizan, 2001), Hal. 227

4 John L. Esposito, The Oxford Encyclopedia ..., hal 227, lihat pula Tahir Mahmood, Family Law Reform in the Muslim World. (New Delhi : The Indian Law Institute, 1972), Hal 247 
yakni ketika Turki mulai melakukan pembaharuan hukum Islam. Adanya pembaharuan hukum ini menstimulus beberapa negara di sekitarnya untuk melakukan pembaharuan serupa termasuk India yang membuat Undang-undang mengenai pernikahan pada tahun 1939.5 Pada undangundang tersebut pemerintah yang ketika itu juga didominasi kekuatan Inggris, menyusun UndangUndang dengan mengadopsi madzhab lain untuk mengakomodir kepentingan masyarakat dalam hukum keluarga. Pasca merdeka UU perceraian 1939 ini masih diaplikasikan di Pakistan, dengan tambahan ordonansi lain yakni MFLO 1961 sebagai acuan hukum Keluarga Islam di Pakistan.

MFLO 1961 merupakan regulasi yang lahir melalui perdebatan, karena kandungan hukum di dalamnya dianggap tidak sesuai dengan madzhab hanafi serta faham ortodoks yang berkembang ketika itu, terutama tentang perceraian. Perceraian bagi masyarakat Pakistan adalah hal yang sangat dianggap tabu dan hak tunggal bagi laki-laki. Estimasi ini mengakar dalam budaya masyarakat Pakistan, akibatnya istri dianggap rendah dan diabaikan haknya. Pengabaian hak dan pengucilan tersebut pada akhirnya membuat para istri lebih memilih hidup menderita dalam pernikahan daripada melepaskannya.

Berbeda dengan kondisi saat ini, meskipun perceraian masih menjadi hal yang tabu dan aib dalam keluarga, namun para istri kini lebih memilih jalan mandiri dan menggunakan haknya. Hal ini terlihat dengan tingginya angka perceraian yang meningkat setiap tahun, dimana perceraian tersebut sebagian besar didominasi oleh gugatan istri. Adanya perkembangan semacam ini juga tidak dapat dilepaskan dari hukum yang berkembang di masyarakat sebagai dasar perbuatan hukum tersebut, yakni UU Perceraian 1939 dan MFLO 1961 yang menjadi acuan hukum perceraian di Pakistan hingga saat ini.

Membicarakan bagaimana undang-undang tersebut kini berlaku tentunya tidak dapat dilepaskan dari bagaimana undang-undang tersebut lahir dan metode yang digunakan dalam pembentukannya, karena kedua hal tersebut akan menentukan kandungan hukum dari regulasi itu sendiri. Oleh karenanya dalam pembahasan ini penting pula untuk menelusuri latar historis kemunculan UU Perceraian 1939 dan MFLO 1961 serta metode reformulasi yang digunakan dalam membuat regulasi tersebut.

\section{METODE PENELITIAN}

Penelitian ini termasuk penelitian normatif(Library Research), atau bisa juga disebut penelitian kepustakaan karena bahan yang digunakan adalah dari Undang-Undang maupun buku-buku yang terkait dengan Reformulasi Hukum Keluarga ataupun Hukum perceraian di Pakistan, dilihat dari data yang digunakan penelitian ini adalah penelitian kualititatif, metode yang digunakan adalah dengan deskriptif analitis.

\section{PAKISTAN DALAM SEJARAH : LATAR HISTORIS IDEOLOGI}

Negara dengan Ibukota Islamabad yang merdeka pada tanggal 14 agustus $1947^{6}$ ini dahulunya merupakan jajahan dari koloni Inggris yang menduduki Asia Selatan sejak tahun 1498. Pada masa pendudukan Inggris ketegangan banyak terjadi pada sistem hukum di negeri ini, terutama ketegangan dalam hal kebijakan dan peradilan yang merupakan benturan antara common law Inggris dan hukum Islam. Sistem hukum tersebut banyak diberlakukan melalui kebijakan prosedural dan peradilan Inggris yang terasa asing bagi umat Muslim maupun non-muslim seperti

5 Tahun 1915-1950 merupakan fase pertama dalam pembaharuan hukum Islam yang distimulus oleh Turki. Lihat Atho' Muzdhar dan Khairuddin Nasution, Hukum Keluarga di Dunia Islam Modern : Studi Perbandingan dan Keberanjakan UU Modern dari Kitab-Kitab /fiqih, (Jakarta : Ciputat Press, 2003) hal 205

6 Meskipun merdeka pada tahun 1947, nama Pakistan sebenarnya telah dipopulerkan sejak tahun 1933 oleh perkumpulan mahasiswa muslim di India Inggris yang dipimpin oleh Khaudari Rahmat ali, nama ini diambil dari bahasa Parsi yakni Pak (suci) dan stan (negara). Lihar Badri Yatim, Eniklopedi Islam..., hal 256 
Hindu. $^{7}$ Pada masa ini penanganan hukum syariah oleh peradilan Inggris diatur berdasarkan putusan dewan rahasia (privy council) yang membuat sistem hukum paduan Inggris-Islam (AngloMuhammadan). ${ }^{8}$ Adanya penerapan hukum yang berbeda ini menurut Mustofa bukanlah akibat usaha pembaharuan Islam begitu saja namun lebih pada upaya peradilan untuk menerapkan hukum Islam. Hanya saja ajaran syariah pada akhirnya mengalami kemunduran dalam beberapa hal seperti persoalan peninggalan harta dan terganti dengan hukum Inggris. Hal ini terjadi karena dalam beberapa persoalan tersebut peradilan seringkali menemui kesusahan menentukan prinsip syariah yang tepat, sehingga harus berpaling pada sistem Inggris. ${ }^{9}$

Kemunduran semacam ini kemudian memunculkan gagasan negara Islam yang dilihat pertama kali oleh Sayyid Ahmad Khan, dimana beliau melihat Islam di India menjadi kekuatan agama minoritas diantara kekuatan Hindu yang mayoritas dan kekuatan Inggris yang menguasai politik dan ilmu pengetahuan, oleh karenanya Islam perlu memperkuat pondasinya terutama dalam hal keagamaan dan hak-hak muslim di India. Gagasan Ahmad khan tersebut akhirnya terealisasi menjadi gerakan pembaharuan yang dikenal dengan gerakan aligarh, ${ }^{10}$ kemudian diteruskan dengan berbagai gerakan keagamaan lain seperti gerakan mujahidin, ${ }^{11}$ gerakan deobandi ${ }^{12}$ dan gerakan khilafat.

Adapun perumusan Pakistan menjadi sebuah negara sendiri pertama kali dicetuskan oleh Muhammad Iqbal melalui pidatonya dalam Liga Muslim India ${ }^{13}$ pada tahun 1930. Mimpi tersebut kemudian direalisasikan oleh Muhammad Ali Jinnah dengan memberikan rancangan tujuan dan visi-misi pembentukan negara Islam pada Liga Muslim India di Lahore tahun 1940. Rancangan Ali Jinnah akan pendirian negara muslim ini mendapat tanggapan yang beragam pula dari para ulama di berbagai golongan. Banyak diantara mereka yang berpendapat pemecahan India Muslim menjadi negara sendiri sebenarnya akan melemahkan kekuatan Islam sehingga beberapa partai politik agama hanya memberikan dukungan secara kabur. ${ }^{14}$ Tujuh tahun kemudian, tepatnya pada tanggal 14 Agustus 1947 Inggris memberikan kedaulatannya pada dewan konstitusi, sejak itulah Pakistan resmi menjadi Negara berdaulat dengan Muhammad Ali Jinnah sebagai gubernur jenderal yang bergelar Quaid-i Azam (Pemimpin Besar).

Sejak dideklarasikan menjadi negara berdaulat, masyarakat Pakistan terus berupaya menerapkan konsep sebuah negara sesuai Islam. Pencarian akan konsep negara Islam ini menjadi

7 Mardani, Hukum Perkawinan Islam di Dunia Islam Modern, (Yogyakarta: Graha Ilmu, 2011) hal 48

8 AA Fyze, Outlines of Muhammadan Law, (Oxford 1955) dalam Mustofa dan Abdul Wahid, Hukum Islam Kontemporer,(Jakarta : Sinar Grafika,2009) hal. 82

9 Musfota dan Abdul Wahid, Hukum Islam Kontemporer..., hal. 84

10 Aligarh merupakan nama sebuah perguruan tinggi tempat Sayyid Khan belajar. Nama itu kemudian menjadi majalah dan menjadi gerakan yang bertujuan untuk melakukan reformasi pendidikan, intelektual agama dan identitas politik Islam yang terpisah serta memperjuangkan hak-hak muslim di India. Lihat John L Esposito, The Oxford Encyclopedia ... hal 227, lihat pula H.A Ali Mukti, Alam Pikiran Islam Modern di India dan Pakistan, (Bandung : MIZAN, 1993)

11 Gerakan mujahidin dipimpin oleh sayyid ahmad syahid, bertujuan memulihkan kekuasaan politik muslim di India barat Laut. Lihat John L Esposito, The Oxford Encyclopedia ... hal 227

12 Deobandi merupakan gerakan yang dipimpin oleh maulana wasim nanautvi (1821-1880) dan maulana mahmud al-hasan (1851-1920), gerakan ini bertujuan mempertahankan warisan tradisional Islam pada masa subordinansi politik. Lihat John L Esposito, The Oxford Encyclopedia ... hal 227

13 Liga muslim India berdiri pada tahun 1906 sebagai organisasi politik yangberasal dari kaum elit muslim berpendidikan barat untuk memperjuangkan kepentingan agama, budaya dan ekonomi kaum muslim India serta mencegah upaya organisasi nasionalis Hindu yang sedang tumbuh. Pada saat itu dalam lingkungan Hindu dikenal gerakan Shuddhi dan Sangatan yang bertujuan memaksakan perpindahan agama terhadap kaum muslim.

14 John L. Esposito dan John o vol, Islam and Democracy, terj. Rahmani Astuti, Demokrasi di Negara-Negara Muslim: Problem dan Prospek, (Bandung : Mizan, 1996) hal 136 
polemik yang panjang dikalangan para ulama, baik ulama tradisional, modern maupun ulama dalam partai-partai muslim. ${ }^{15}$ Konflik ideologi ini pada akhirnya membawa pengaruh pada proses pembentukan konstitusi yang dapat dikatakan lama, yakni memakan waktu hampir sembilan tahun (1947-1956).

Konstitusi 1956 sebagai konstitusi pertama Pakistan masih terbangun dengan nuansa warisan koloni Inggris, menyangkut perundang-undangan, model hukum dan model pendidikannya. Menurut Konstitusi yang bersifat demokratis sekaligus Islami ini, Pakistan merupakan sebuah republik Islam dengan sistem demokrasi Parlementer model Westminster sehingga dalam konstitusi ini Pakistan disebut dengan "Republik Islam Pakistan". ${ }^{16}$ Sedangkan sistem pemerintahan yang diajukan oleh Majelis nasional merupakan sistem yang berpedoman pada hasil Liga Muslim India di Lahore pada tahun $1940 .{ }^{17}$

Adanya perundang-undangan ini memunculkan suasana republik Islam dengan karakter religius hingga tahun 1962 ketika perubahan konstitusi pada masa Presiden Agha Mohammed Yahya Khan, yang menghilangkan nama Islam dalam menyebut republik Pakistan. Sebagai kompensasi perubahan konstitusi ini terbentuklah dua lembaga yakni dewan penasihat ideologi Islam $^{18}$ dan lembaga pengkajian Islam. ${ }^{19}$

Persoalan ideologi dan penafsiran mengenai Islam terus bergulir di Pakistan, hingga mengikat erat pada keseluruhan proses politik dan pembentukan konstitusi. Hal ini terbukti dengan adanya pergantian konstitusi Pakistan setiap pergantian masa kepala pemerintahan. ${ }^{20}$ Inilah gambaran dari tradisi yang telah mengakar dalam pembuatan hukum di negara Pakistan, bahwa Pakistan merupakan negara yang memiliki karakter dengan nuansa Islam yang sangat kental. Corak inilah yang nantinya juga akan mewarnai hukum keluarga yang diterapkan di Negara Pakistan, yakni hukum berdasarkan tradisi teo-demokrasi.

\section{HUKUM KELUARGA ISLAM YANG BERKEMBANG DI PAKISTAN}

Semenjak Pakistan merdeka pada tahun 1947 hingga tahun 1960, negara ini belum merumuskan hukum keluarga yang tepat bagi masyarakatnya, sehingga regulasi mengenai hukum keluarga yang ada ketika itu masih merupakan warisan dari budaya India. Salah satu contoh peraturan yang masih dipakai adalah Peraturan Hukum Keluarga Muslim India 1937 (The Muslim Personal Law Application Act 1937) yang diterapkan di Bengal Timur. ${ }^{21}$ Beberapa aturan lain diantaranya adalah The West Punjab Muslim Personal Law Application Act 1948, UU perwalian (The Guardians

15 Mardani, Hukum Perkawinan Islam... hal. 47, lihat pula John L Esposito dan John O Voll, Islam and Democracy... hal. 137

16 Pasal 1 Konstitusi 1956 berbunyi "Pakistan shall be a Federal republic to be known as the Islamic Republic of Pakistan, hereinafter referred to be Pakistan",sumber : http://Pakistanconstitutionlaw.com diakses pada tanggal 28 september 2014.

17 Sistem pemerintahan yang ditawarkan melalui konferensi ini adalah sistem yang berdasarkan pada al-Qur'an dan Hadits.

18 Advisory council of Islamic ideology adalah dewan yang bertugas menunjuk seluruh hukum, baik itu hukum yang sudah ada maupun yang akan dibuat dengan tujuan penyelarasan pada ak-Qur'an dan sunnah serta memberikan rekomendasi-rekomendari kepada pemerintah Pakistan agar masyarakat menjadi lebih baik. Lihat Musahadi HAM, Continuity And ChangeReformasi Hukum Islam : Belajar Pada Pemikiran Muhammad Iqbal dan Fazlur Rahman, (Semarang : Walisongo Press, 2009) hal 46.

19 Mardani,Hukum Keluarga Islam .... hal 47

20 Konstitusi pertama diamandemen tahun 1962, selanjutnya pada masa Yahya Khan kembali diamandemen pada tahun 1969. Penguasa selanjutnya yakni Jenderal zulfikar Ali Butho membuat konstitusi baru diawal kekuasaanya tahun 1973 yang kemudian direvisi oleh Zia ul-Haq hingga 8 kali. Akhirnya Revisi ke delapan pada tahun 1985 dianggap sebagai konstitusi final dan baru yang berisi pengukuhan semua keputusan zia ulHaq.

21 Tahir Mahmood, Family Law Reform ... hal 247 
and Wards Act, 1890), UU Validasi wakaf 1913-1920 dan UU Wakaf tahun 1930, Pencegahan Pernikahan dini (Indian Child Marriage Restrain Act, 1929) dan UU Perceraian Islam tahun 1939 (Dissolution of Muslim Marriage Act, 1939). ${ }^{22}$

Sebagai upaya pembentukan hukum Islam yang dapat diaplikasikan sebagai hukum negara, pemerintah Pakistan kemudian membentuk sebuah komisi pembentukan hukum Islam (Family Law Commissions) ${ }^{23}$ pada bulan Agustus 1955. Komisi ini mempunyai tugas melakukan survey tentang hukum berkaitan dengan hukum keluarga seperti pernikahan, perceraian, nafkah dan beberapa persoalan tambahan dalam hukum keluarga. Tujuan dari survey yang dilakukan komisi ini adalah untuk menemukan sistem hukum yang sesuai, terutama menyangkut hak perempuan agar perempuan mendapatkan tempat yang tepat di masyarakat. ${ }^{24}$

Selanjutnya pada bulan Juli 1956, berdasarkan survey yang dilakukan, FLC menghasilkan format hukum Islam yang disetujui oleh enam dari tujuh anggotanya. Adapun anggota ketujuh dan beberapa pemuka agama di pemerintahan tidak menyetujuinya karena melihatnya terlalu liberal. Setelah melalui perdebatan dengan kelompok ortodoks, akhirnya rancangan dari komisi ini dinilai cukup komprehensif dan dapat direkomendasikan menjadi sebuah aturan perundang-undangan di Pakistan. Berdasarkan rekomendasi tersebut akhirnya lahirlah ordonansi hukum keluarga muslim pertama di Pakistan yaitu MFLO 1961 yang merupakan singkatan dari Muslim Family Law Ordinance 1961 atau yang dikenal dengan nama Mudawwanah al-ahwal al-Syakhsiyyah. ${ }^{25}$

Seperti disebutkan sebelumnya MFLO tahun 1961 merupakan hasil survey yang disesuaikan dengan kebutuhan keluarga Pakistan ketika itu, sekaligus aturan yang dibuat dengan tujuan merevisi undang-undang yang telah ada sebelumnya. Oleh karena itu MFLO mempunyai cakupan yang lebih luas dibandingkan UU Perceraian 1939 (Dissolution of Muslim Marriage act 1939) dan dapat dikatakan sebagai pengukuh peraturan yang ada sejak tahun 1929. ${ }^{26}$ Setelah mengeluarkan MFLO, pemerintah kemudian membuat konstitusi lanjutan yaitu West Pakistan Muslim Personal Law Act 1962, yang disahkan untuk mengakomodasikan kembali ajaran-ajaran Islam dalam konstitusi terdahulu. Sebagai upaya antisipasi dan penyelesaian terhadap sengketa-sengketa keluarga yang mungkin ada, pemerintah selanjutnya membentuk regulasi tahun 1964 tentang adanya Peradilan Keluarga (West Pakistan Family Court Act, 1964). Beberapa perkara keluarga yang disebutkan di dalam regulasi ini antara lain : Putusnya Perkawinan (dissolution of muslim marriage), Mahar (dower), Nafkah (maintenance), ganti rugi hak suami istri atas perkawinan (restitution of conjugal rights), pemeliharaan anak (custody of children) dan perwalian(guardianship). ${ }^{27}$

Regulasi tersebut kemudian mengalami beberapa kali amandemen, yakni pada tahun $1971{ }^{28}$ $1997^{29}$ hingga amandemen terakhir pada bulan oktober tahun 2002. Pada amandemen terakhir ini ada beberapa materi penambahan yang masuk dalam cakupan peradilan keluarga, yaitu meliputi : perceraian termasuk khulu, mahar, nafkah, ganti rugi hak suami istri dalam perkawinan, pemeliharaan anak dan hak kunjungan orangtua untuk bertemu, perwalian, jactitation of marriage, hadiah perkawinan, harta kekayaan pribadi dan milik istri.

22 Beberapa dari undang-undang ini masih diterapkan pasca Pakistan merdeka, lihat Tahir Mahmood, Family Law Reform ... hal. 253

23 Komisi ini mempunyai tujuh personil dengan ketua Khalifa Shujahuddin, setelah beliau meninggal dunia digantikan oleh wakilnya yakni Mian Abdur Rashid (Chief Justice)

24 Ahmed K. Marriage Commision Report x-Ray (Karachi 1959), 33 dalam Tahir Mahmood, Family Law reform ... hal. 248

25 Tahir Mahmood, Family Law Reform ... hal 248-249, ,lihat pula Mardani, Hukum Keluarga Islam.... hal 48

26 Mardani, Hukum Keluarga Islam ... hal 48

27 Naheda Mehboob Ellahi (Advocate Supreme Court of Pakistan), Journal, Family and Judicial Protection, hal 8

28 Regulasi ini diamandemen melalui Family Court Amendement Act, XXIV of 1971. Adapun materi yang menjadi tambahan dalam Regulasi baru ini adalah mengenai jactitation of marriage.

29 Pada tahun 1997 regulasi peradilan keluarga diamandemen melalui Family Court Amendement Act XVI of 1997 dengan materi penambahan hadiah dalam pernikahan (Dowry). 
Selain perundang-undangan di atas, ada beberapa peraturan lain mengenai hukum keluarga yang masih diterapkan di Pakistan hingga tahun 1987, yakni :

1. Undang-undang tentang mahar dan hadiah penggantian 1976 (Dowry and Bridal Gifts Restriction,1976) dan amandemennya yakni ordonansi mahar dan hadiah pengantin tahun 1980

2. Undang-Undang wakaf tahun 1979

3. Konstitusi 1985 tentang operasional dan efektivitas peradilan shariah federal dan peradilan banding.

4. Pakistan : reform and protection of personal laws 1947-1987. ${ }^{30}$

\section{LEGISLASI HUKUM PERCERAIAN DI PAKISTAN}

Perceraian di negara Pakistan hingga saat ini diatur dalam beberapa peraturan daerah (act), diantaranya adalah UU Perceraian hasil warisan India (Dissolution of Muslim Marriage Act, 1939) dan Ordonansi Hukum Keluarga Islam (Muslim Family Law Ordinance, 1961). Meskipun Pakistan mempunyai dua hukum untuk perceraian, namun sebenanya MFLO melengkapi prosedur yang belum tercantum di dalam UU 1939. Kedua peraturan ini mempunyai latar pembentukan yang berbeda.

\section{Perceraian menurut Dissolution of Muslim Marriage Act, 1939}

UU Perceraian 1939 terbentuk sebagai sebuah implementasi pengaruh warna madzhab hanafi yang kuat di masyarakat ketika itu. Menurut aturan yang berkembang di masyarakat, istri mempunyai keterbatasan dalam hal penuntutan cerai, sehingga talak tetap menjadi hak unilateral bagi suami. Ketatnya hukum perceraian ketika itu ternyata menimbulkan dampak yang besar di masyarakat, yakni adanya pemurtadan secara masal. Para istri yang tidak nyaman dengan rumah tangga mereka akhirnya ramai mengambil jalan ekstrim, yakni berpindah dari agama Islam. ${ }^{31}$

Kondisi yang demikian pada akhirnya menggerakkan para ulama untuk mencari solusi, yakni berijtihad untuk menemukan dasar hukum hak perceraian bagi kedua belah pihak. Pada saat bersamaan, Inggris yang saat itu menduduki wilayah India memandang bahwa hukum syariah di masyarakat membutuhkan adopsi hukum lain, karena hukum yang ada tidak memberikan hak-hak wanita dengan semestinya.Atas dasar inilah kemudian dibentuk UU tahun 1939. Berangkat dari latar belakang yang demikian UU Perceraian 1939 lahir dengan nuansa gender yang kental, salah satunya tercermin melalui pasal 2 tentang hak pengajuan cerai bagi istri. Menurut regulasi ini, seorang istri diperbolehkan mengajukan cerai apabila terdapat hal-hal sebagaimana ditentukan undang-undang yang terdapat pada suami. Pasal 2 UU ini masih diberlakukan saat ini dan dikukuhkan keberadaanya oleh MFLO 1961.

Aturan dasar lain dalam UU Perceraian 1939 yang masih dipakai hingga saat ini adalah hukum perceraian bagi istri yang murtad. Sebagaimana pasal 4 UU ini menetapkan jika seorang istri meninggalkan Islam, maka dengan sendirinya ia kehilangan hak untuk mengajukan gugatan cerai pada suami, ${ }^{32}$ namun seorang suami dapat menceraikan istrinya atas dasar istri murtad sesuai dengan MFLO 1961.

30 Mardani, Hukum Keluarga Islam hal. 48

31 Kuna, Makalah, Perceraian dalam Perundan-Undangan Pakistan (Tekaah Kritis Terhadap Undang-Undang Perceraian 1939 dan MFLO 1961)http://kursiana2811.blogspot.com. Diakses pada tanggal 26 september 2014.

32 Pasal 4 UU Perceraian 1939 berbunyi "the renunciation of Islam by a marriage woman or her conversion to a faith other than Islam shall not by Itself operate to dissolve her marriage. Provided that after such renunciation, or conversion, the woman shall be entitled to obtain a decree for the dissolution of her marriage on any of the grounds, mentioned in section 2. Provided further that the provision of thus section shall not apply to a woman converted to Islam from some other faith who re-embraces her former faith. 


\section{Perceraian dan Prosedurnya menurut The Muslim Family Law Ordinance 1961}

Sebagaimana disinggung sebelumnya, MFLO terbentuk berdasarkan survey yang dilakukan oleh komite pembentukan hukum Pakistan, oleh karenanya rancangan yang kini menjadi MFLO merupakan hukum aplikatif yang sesuai dengan masyarakat Pakistan. Regulasi mengenai perceraian diatur dalam pasal 7 dan 8 MFLO 1961.

Berdasarkan regulasi ini, putusnya perkawinan di negara Pakistan dapat terjadi melalui empat cara, yakni :

\section{a. Cerai atas Inisiatif Suami}

Setelah menikah, seorang suami mempunyai hak unilateral yang melekat pada dirinya atas perceraian, namun hak ini dapat dibatasi melalui kontrak pernikahan yang dikenal dengan nama Nikkahnamma ${ }^{33}$. Shighat talak yang diakui dalam hukum Pakistan tidak terbatas pada talak didepan pengadilan saja, suami dapat mengucapkan talak secara lisan maupun dengan tulisan di luar pengadilan. ${ }^{34}$ Namun setelah suami mengucapkan talak di luar pengadilan ini, dia mempunyai kewajiban melaporkan peristiwa talak kepada "union council" 35 , untuk dikeluarkan pengumuman cerai atasnya. ${ }^{36}$ Apabila suami mengabaikan melakukan pencatatan talak yang diucapkan, maka ia dapat dikenakan hukuman 1 tahun penjara atau denda 5.000 rupee. ${ }^{37}$ Dalam laporannya, suami juga diharuskan menyebutkan alamat tinggal mantan istri agar kantor pemerintahan dalam mengumumkan kepada istri dan keluarga terdekat istri lewat surat resmi atau surat kabar jika istri tidak diketahui keberadaanya. Surat pengumuman yang dibuat oleh dewan perkawinan selanjutnya juga diberikan kepada dewan arbitrase (arbitration council) untuk baru kemudian dilakukan rekonsiliasi kedua belah pihak, dan menyelesaikan perkaranya jika mungkin. ${ }^{38}$

Kewenangan dewan arbitrase ini ditentukan dalam pasal 7 ayat (4) MFLO, dimana dewan ini hanya bertugas mendamaikan kembali pasangan dalam waktu 30 hari setelah menerima surat pernyataan talak dari suami. Jika dalam kurun waktu tiga puluh hari tersebut tidak ditemukan kesepakatan perdamaian, maka talak berlaku efektif dan masa iddah dapat diberlakukan selama 90 hari ${ }^{39}$ sejak keluarnya surat pernyataan talak. ${ }^{40}$ Pengecualian dapat diberlakukan apabila istri yang ditalak tersebut tengah hamil. Sesuai MFLO pasal 8 masa iddah yang ditanggung oleh istri adalah sampai ia melahirkan atau 90 hari jika istri melahirkan dalam kurun waktu kurang dari 90 hari.

Prosedur semacam ini dibuat untuk melindungi kedua belah pihak, terutama istri dari perceraian yang tidak tercatat. Kasus terbaru ketika itu sebagaimana disebutkan oleh

33 Nikahnama merupakan perjanjian tertulis yang ditandatangani saat pernikahan, dimana perjanjian ini memberikan hak kepada istri untuk meminta bercerai jika suaminya melakukan hal-hal yang disepakati untuk tidak dilakukan dalam nikahnama. Menurut kitab fiqh perjanjian ini disebut juga dengan ta'liq talaq.

34 Pasal 7 ayat (1) MFLO berbunyi "Any man who wishes to divorce his wife shall, as soon as may be after the prounouncement of talaq in any kind from whatsoever ..."

35 Union council merupakan dewan keagamaan kota yang ditunjuk berdasar konstitusi Basic Democracies Order 1959, mempunyai kewenangan hukum sesuai undang-undang yang menyebutnya, lihat pasal 2 (d) The Muslim Family Law Ordinance, 1961.

36 Pasal 7 ayat (1) MFLO

37 Pasal 7 ayat (2) MFLO yang berbunyi "whoever contravenes the provisions of sub-section(1) shall be punishable with the simple imprisonment for a term which may extend to one year or with fine wich may extend to five thousand rupees or with both".

38 Pasal 7 ayat (4) MFLO, berbunyi "within thirty days of the receipt of notice under sub-section(1), the chairman shall constitute an Arbitration Council for the purpose of bringing about a reconciliation between the parties, ....."

3990 hari berangkat dari ketetapan fiqih yakni tiga kali quru', yang dihitung berdasarkan rata-rata siklus haidl normal seorang wanita.

$40 \quad$ Pasal 7 ayat (3) MFLO 
Barrister Ali Shaikh dalam bukunya Law Divorce and Khula in Pakistan, "perceraian tidak tercatat telah membuat seorang wanita dijerat kasus kriminal perkawinan". ${ }^{41}$ Kasus tersebut muncul ketika mantan suaminya melakukan komplain atas pernikahan baru sang istri, oleh karenanya wanita tersebut terjerat kasus bigami dan dihukum dengan kurungan 7 tahun penjara. Talak yang dijatuhkan oleh mantan suami tersebut tidak dapat dibuktikan karena tidak ditemukan bukti tertulis. ${ }^{42}$.

Prosedur cerai yang diatur dalam regulasi ini mempunyai beberapa implikasi lanjutan. Sesuai yang disebutkan oleh Tahir Mahmood dalam bukunya Family Law Reform in the Muslim World, setidaknya ada empat dampak dari hukum ini, yaitu :

1) Hukum ini memberikan waktu bagi kedua pasangan untuk melakukan mediasi.

2) Konsep talak tiga tidak diakui dalam MFLO, karena bagaimanapun shighat talak yang diucapkan tetap dituliskan sebagai talak tunggal.

3) Prosedur ini tidak membedakan antara perceraian sebelum dukhul atau setelah dukhul, karena semua bentuk perceraian mempunyai masa mediasi 30 hari dan iddah akan berlaku efektif setelahnya.

4) Talak tiga dapat efektif hanya setelah melalui prosedur perceraian seperti yang lain, yakni setelah lewat 90 hari.

5) Pasal 8 regulasi ini memperpanjang prosedur perceraian lain seperti talaq-i tafweez dan khulu'. ${ }^{43}$

\section{b. Cerai oleh istri}

Cerai yang diajukan atas inisiatif istri hanya dapat dilakukan apabila istri mendapat hak cerai. Hak cerai tersebut biasanya telah tertulis didalam nikahnama ketika perkawinan dilakukan. Apabila suami terbukti melanggar kesepakatan dalam nikahnama, maka istri dapat mengajukan gugatan perceraian ke pengadilan. Namun jika dalam pernikahannya istri tidak mendapat hak melalui nikkahnama, maka istri dapat mengajukan khula atau khulu'.

c. Khulu'

Pengertian khula yang secara literatur berarti "melepaskan ikatan", adalah perceraian yang diinisiasi oleh istri dan diwakilkan kepada pengadilan. Untuk menggunakan hak khula ini seorang istri harus menggunakan sumpah dan berdasarkan alasan-alasan yang ditentukan oleh perundang-undangan yakni West Pakistan Family Law Ordinance. Prosedur pengajuan khulu' diatur sebelumnya dalam pasal 2 UU Perceraian tahun 1939. Aturan dalam regulasi ini kemudian masih diterapkan dan dikukuhkan oleh MFLO 1961. Menurut regulasi tersebut seorang istri dapat mengajukan izin perceraian ke pengadilan, apabila dalam pernikahannya terjadi hal-hal sebagai berikut :

1) Suami mafqud atau tidak memberi kabar dalam kurun waktu empat tahun. ${ }^{44}$

2) Suami mengabaikan tanggungjawab memberi nafkah selama dua tahun. ${ }^{45}$

3) Suami melakukan tindak kriminal dan dipenjara selama tujuh tahun atau lebih. ${ }^{46}$

4) Suami gagal memenuhi kewajibannya tanpa ada alasan yang jelas selama kurun waktu tiga tahun. ${ }^{47}$

5) Suami telah impoten sejak awal pernikahan dan terus berlanjut hingga tuntutan diajukan. ${ }^{48}$

41 Barrister Ali Shaikh, Artikel, Law Divorce and Khula in Pakistan, hal.3

42 Barrister Ali Shaikh, Artikel, Law Divorce and Khula in Pakistan, hal.3

43 Tahir Mahmood, Family Law Reform ... hal. 251

44 Pasal 2 ayat (1) Dissolution of Muslim Marriage Act 1939

45 Pasal 2 ayat (2) Dissolution of Muslim Marriage Act 1939

$46 \quad$ Pasal 2 ayat (3) Dissolution of Muslim Marriage Act 1939

47 Pasal 2 ayat (4) Dissolution of Muslim Marriage Act 1939

48 Pasal 2 ayat (5) Dissolution of Muslim Marriage Act 1939 
6) Suami gila dalam kurun waktu dua tahun, atau menderita kusta, atau penyakit kelamin yang kronis. ${ }^{49}$

7) Istri meminta hak kedewasaan, dimana ia dinikahkan oleh walinya sebelum berusia 16 tahun dan menolak pernikahan sebelum dia berusia 18 tahun. Ketentuan ini ditetapkan dengan syarat pernikahan belum sempurna (belum $d u k h u l) .{ }^{50}$

8) Suami melakukan kekerasan. ${ }^{51}$

9) Alasan-alasan lain yang dipandang valid untuk mengajukan perceraian menurut hukum Islam..$^{52}$

MFLO kemudian menambahkan satu lagi alasan dari sembilan alasan tersebut, yakni jika seorang suami melakukan pernikahan lagi baik itu bigami atau poligami.

Setelah istri mengajukan gugatan perceraian, pengadilan keluarga (Family court) selanjutnya akan mengabarkan putusan kepada dewan union tentang adanya perceraian. Selanjutnya prosedur kembali berlangsung seperti prosedur talak yag diatur dalam MFLO pasal 7. Selama mengajukan gugatan khula, biasanya seorang istri diwajibkan mengembalikan mahar dan harta lain yang diterima dari suami sebagai zar-i khula. Adapun hadiah yang berasal dari keluarga suami tidak termasuk dalam zar-i khula yang wajib dikembalikan. ${ }^{53}$

\section{d. Talaq - e Tafweez dan Mubara'ah}

Bentuk perceraian yang terakhir ini merupakan perceraian yang terjadi atas kesepakatan kedua belah pihak. Jenis perceraian ini tidak membutuhkan campur tangan pengadilan, oleh karenanya prosedur talaq-e tafweez lebih cepat. Sesuai dengan pasal 8 MFLO, kedua pasangan cukup datang ke kantor pemerintahan, selanjutnya mereka diharuskan menandatangani akta kesepakatan perceraian. Setelah itu talak dapat dinyatakan efektif, masa iddah berlaku dan kantor pemerintahan dapat mengeluarkan sertifikat talaq.

\section{Implementasi Hukum Perceraian (Problem Sosiologis Pasca Regulasi MFLO 1961)}

Perceraian dalam masyarakat Pakistan sejak dulu dikenal sebagai sesuatu yang sakral dan terlarang. Hal ini berakar dari ajaran madzhab hanafi yang begitu protect terhadap pernikahan dan hanya memberikan hak ini kepada suami. Adanya regulasi yang memberikan hak mengajukan cerai kepada istri ternyata juga tidak menuai respon yang antusias bagi beberapa golongan. Diantaranya adalah masyarakat pedalaman yang menganggap perceraian sebagai sesuatu yang rendah.

Menurut sebagian masyarakat Pakistan perceraian adalah perbuatan tidak terhormat, sehingga pelakunya juga diberikan gelar khusus sepert zhan thalaq (laki-laki yang telah bercerai). Panggilan yang demikian menunjukkan adanya status sosial yang rendah di masyarakat sehingga mereka enggan melakukan perceraian meskipun sangat terdesak. Disamping itu mayoritas wanita di tahun awal Undang-undang ini dibuat (1970) tidak memiliki penghasilan sendiri, sehingga dalam mencukupi kebutuhannya mereka sangat bergantung pada penghasilan suami. Adapun faktor terakhir rendahnya perceraian ketika itu adalah pengembalian khulu' yang nominalnya dianggap besar oleh sebagian masyarakat yang hendak mengajukan cerai.

Namun, Kondisi yang demikian secara bertahap berubah seiring dengan berkembangnya zaman. Sebagaimana diberitakan di media masa, angka perceraian di Pakistan mengalami

49 Pasal 2 ayat (6) Dissolution of Muslim Marriage Act 1939

$50 \quad$ Pasal 2 ayat (7) Dissolution of Muslim Marriage Act 1939

51 Pasal 2 ayat (8) Dissolution of Muslim Marriage Act 1939

52 Pasal 2 ayat (9) Dissolution of Muslim Marriage Act 1939

53 Barrister Ali Shaikh, Artikel, Law of Divorce and Khula In Pakistan, hal. 4 
kenaikan setiap tahunnya. Di Islamabad tercatat ada 557 kasus perceraian yang masuk di dewan pengadilan Islam. Angka ini berbeda jauh dengan tahun-tahun sebelumnya seperti tahun 2002 yang tercatat ada 208 kasus perceraian yang masuk dan 80 kasus perceraian di tahun $1998 .^{54}$ Kondisi serupa juga terjadi di beberapa kota seperti Karwachi dan Pashtun, meskipun di Pashtun masyarakatnya masih sangat konservativ dan menganggap perceraian merupakan aib keluarga. ${ }^{55}$

Menurut Shabina Ayaz, direktur sebuah yayasan perempuan di Pashtun, perceraian banyak terjadi atas gugatan istrinya. Beberapa penyebabnya antara lain karena sang istri telah memiliki penghasilan sendiri, adanya kekerasan dalam rumah tangga dan juga suami terbukti melakukan pernikahan lagi. Namun ada tantangan lain yang harus diterima oleh wanita yang meminta cerai di daerah ini, yakni ditelantarkan keluarga karena dipandang sebagai aib hingga ancaman kekerasan berupa pembunuhan. Kejadian ini pernah terjadi pada Ghazala Haved, seorang penyanyi yang menikah pada tahun 2010 dan meninggal pada 2012 karena ditembak oleh suami saat meminta cerai. ${ }^{56}$

Permasalahan lain yang muncul pasca regulasi ini ditetapkan adalah kurangnya kesadaran suami untuk melaporkan talaknya ke pengadilan, bahkan tercatat hanya sekitar $10 \%$ yang telah melaporkan secara sukarela. Penyebab kondisi semacam ini diduga karena faktor ringannya hukuman yang tercantum dalam MFLO 1961, sehingga butuh upaya lebih untuk mengefektivkan regulasi tersebut. ${ }^{57}$

\section{ANALISIS LEGISLASI HUKUM PERCERAIAN : REGULASI DAN METODE}

\section{Gender sebagai Warna Reformulasi Hukum Perceraian}

Tahun 1960 merupakan sebuah tahun yang berat bagi Pakistan, karena tahun awal kemerdekaanya ini diwarnai dengan perdebatan sengit antara berbagai kelompok Islamkonservativ modern dan sekuler- dalam menentukan struktur hukum Islam yang relevan untuk Pakistan. ${ }^{58}$ Namun adanya perdebatan ini memunculkan banyak pemikir baru yang memberikan kontribusi pemikirannya untuk reformulasi hukum Islam, diantaranya Fazlur rahman, Maududi dll yang masuk dalam anggota advisory council of Islamic ideology. Para pemikir baru yang muncul tersebut membawa konsep medernis terutama untuk memperjuangkan hak-hak perempuan.

Hal itu terlihat melalui MFLO 1961 yang tidak melepaskan diri dari pengaruh kesetaraan gender. Berbeda dengan Turki yang menuntut persamaan hak antara laki-laki dan perempuan secara besar-besaran, Pakistan tidak melakukan gerakan serupa. Namun pemerintah agaknya merefleksikan diri dari maraknya gerakan feminis di negara lain, hal ini tampak dari pertimbangan yang dilakukan dalam merumuskan MFLO dengan melakukan survey terhadap masyarakat Pakistan dan negara sekitarnya. Disamping itu tujuan adanya Komisi pembentukan hukum seperti yang disinggung sebelumnya adalah untuk memberikan tempat yang tepat bagi perempuan di masyarakat. Meskipun ketika pembentukannya banyak mendapat kontra dari kelompok ortodoks, namun usaha dari komite ini patut mendapatkan apresiasi.

Kesetaraan gender pada akhirnya tampak pada isi dari MFLO sendiri, contohnya pada pasal 8 yang mengakui adanya perceraian dengan kesepakatan (talaq e tafweez dan mubara'ah), kesepakatan tersebut membutkikan bahwa suara perempuan di Pakistan juga

54 Sumber : http://muslimdaily.net, diakses pada tanggal 28 september 2014

55 Sumber : http://batampos.co.id. Laporan oleh Mudassar Shah 6 Maret 2013, diakses pada tanggal 28 september 2014

56 Sumber : http://batampos.co.id. Laporan oleh Mudassar Shah 6 Maret 2013, artikel ini pertama kali disiarkan pada program berita Asia caling www.Asiacalling.org, diakses pada tanggal 28 september 2014.

57 Kuna, Makalah, Perceraian dalam Perundan-Undangan Pakistan (Tekaah Kritis Terhadap Undang-Undang Perceraian 1939 dan MFLO 1961)http://kursiana2811.blogspot.com. Diakses pada tanggal 26 september 2014.

58 Musahadi HAM, Continuity and Change ..., hal 45 
patut untuk dipertimbangkan. Selanjutnya persamaan laki-laki dan perempuan dalam bidang sosial juga tampak pada pasal 9 ayat (1) yang memberikan hak bagi istri untuk melakukan gugatan cerai apabila suami terbukti tidak dapat berlaku adil pada istri-istrinya.

\section{Metode Reformasi Hukum Perceraian di Pakistan.}

Penyelesian persoalan hukum dalam suatu wilayah tidak dapat dilepaskan dari warna madzhab dan kondisi sosial masyarakat itu sendiri. Hal ini berlaku pula pada Republik Pakistan yang didominasi oleh madzhab Hanafi dalam hukum-hukumnya. Sebagaimana disebutkan oleh Tahir Mahmood bahwa negara selalu menggunakan madzhab yang dianut untuk menyelesaikan persoalan hukum, namun dalam beberapa kasus tertentu terdapat pengecualian sehingga muncul teknik atau metode yang berbeda dalam pembentukan hukum. Setidaknya ada empat metode reformulasi hukum yang telah dirangkum oleh Tahir Mahmood, sebagai berikut:

a. Intra Doctrinal Reform, yakni reformasi hukum keluarga Islam yang dilakukan dengan menggabungkan pendapat beberapa madzhab atau mengambil pendapat lain selain madzhab yang dianut. ${ }^{59}$

b. Ekstra Doktrinal Reform, yakni pembaharuan hukum dengan cara memberikan penafsiran yang baru terhadap nash yang telah ada. ${ }^{60}$

c. Regulatory Reform.

d. Codification

Membahas persoalan metode reformulasi Undang-Undang Perceraian di Pakistan yakni UU Perceraian 1939 dan MFLO 1961, setidaknya ada dua metode berbeda yang dapat ditangkap dalam pembentukan regulasi tersebut. Pembentukan UU Perceraian 1939 dalam sejarahnya tidak lepas dari adanya fenomena murtad yang dilakukan oleh para istri karena ketatnya madzhab negara saat itu, yakni madzhab hanafi. Sebagai bentuk solusi atas permasalahan ini, pemerintah kemudian mengadopsi fiqih madzhab lain yang membolehkan istri mengajukan perceraian yakni melalui fiqih madzhab Maliki. Bentuk adopsi atau talfiq seperti ini digunakan pemerintah Pakistan dalam membentuk hukum sehingga memberikan karakter hukum yang luwes.

Adapun metode reformulasi berbeda terlihat pada pembentukan hukum selanjutnya. MFLO terbentuk berdasarkan hasil survey para ulama dengan melihat kondisi masyarakat ketika itu, kemudian melakukan pemaknaan ayat dan merumuskan kembali dalam prosedur yang tidak menyalahi aturan dasar (al-Qur'an dan sunnah). Metode seperti ini menurut tahir mahmood termasuk dalam kategori ekstra doctrinal reform, yakni dengan cara berijtihad kembali tanpa melihat mufassir sebelumnya. Meskipun metode ini menimbulkan polemik diantara ulama ketika itu, namun ternyata produk hukum yang dihasilkan lebih aplikatif dan sesuai kebutuhan masyarakat hingga saat ini.

\section{PENUTUP}

Regulasi mengenai perceraian di Pakistan hingga saat ini mengacu pada Dissolution of Muslim Marriage act 1939 dan The Muslim Family Law Ordinance, 1961 yang dibentuk 53 tahun silam. Kedua regulasi ini memiliki latar pembentukan yang berbeda. UU Perceraian 1939 dibentuk berdasarkan permasalahan keluarga ketika itu, yakni banyaknya wanita yang murtad karena inisiasi perceraian hanya terletak pada suami. Sebagai bentuk solusi pemerintah kemudian mengadopsi

59 Tahir Mahmood, Family Law Reform ....hal. 267-269, dalam Atho'Muzdhar dan Khairuddin, Hukum Keluarga ... hal. 207.

60 Tahir Mahmood, Family Law Reform .... hal. 267-269, dalam Atho' Muzdhar dan Khairuddin, Hukum Keluarga ... hal. 208. 
aturan dari madzhab maliki sebagai regulasi baru perceraian di tahun itu. sedangkan MFLO 1961 dibentuk berdasarkan hasil survey komite pembentukan hukum yang melakukan penelitian terhadap kondisi sosial masyarakat, budaya dan isue baru yang berkembang ketika itu. Isi MFLO juga melengkapi hukum perceraian dalam UU Perceraian 1939 yang dianggap belum ada.

Lahirnya dua undang-undang perceraian ini merupakan bukti dari inisiatif bangsa Pakistan sendiri dalam membentuk undang-undang, meskipun melakukan pembacaan pada negara sekitar, namun produk yang dihasilkan terbukti berbeda dengan negara lain seperti Mesir, Turki dan sebagainya. Adanya regulasi ini juga tidak serta merta diterima oleh semua kalangan, bahkan mendapat penolakan dari para kaum tradisional, karena dianggap sekuler dan sangat menyimpang dari madzhab besar mereka yakni madzhab hanafi.

Adapun metode reformulasi yang digunakan, terlihat ada dua perbedaan dari dua regulasi tersebut. UU Perceraian 1939 yang mengadopsi madzhab maliki menggunakan metode Talfiq atau Intra Doctrinal Reform, sedangkan MFLO yang terbentuk berdasarkan survey menggunakan metode ijtihad dengan pembacaan sosial atau Ekstra Doctrinal Reform.

Pasca keluarnya regulasi mengenai perceraian ini, ternyata masih ditemukan beberapa problem sosial diantara masyarakat Pakistan. Diantaranya adalah kurang efektifnya peraturan tersebut karena estimasi tabu perceraian yang masih mengakar di masyarakat, sehingga beberapa masyarakat pada daerah konservatif lebih memilih tidak bercerai daripada menjadi aib keluarga. Sedangkan sebagian besar wanita Pakistan yang telah mandiri dan berpenghasilan sendiri, lebih memilih jalan perceraian ketika terjadi permasalahan di dalam rumah tangganya. Hal ini biasanya dipicu oleh faktor kekerasan dalam rumah tangga, atau suami yang melakukan pernikahan lagi. Adapun bagi suami sendiri, hingga beberapa tahun setelah MFLO 1961 diundangkan, hanya tercatat sekitar 10\% yang melaporkan perceraiannya secara langsung, sedangkan sebagian besar lainnya melaporkan setelah memakan waktu yang lama atau setelah istri melaporkan kepada union council.

\section{DAFTAR PUSTAKA}

\section{Buku}

Ellahi, Naheda Mehboob. (Advocate Supreme Court of Pakistan), Journal, Family and Judicial Protection

Esposito, John L.2001.The Oxford Encyclopedia of The Modern Muslim World, terj. Eva YN dkk, Ensiklopedia oxford : dunia Islam modern. Bandung : Mizan

Esposito, John L. dan John ovol. 1996. Islam and Democracy, terj. Rahmani Astuti, Demokrasi di Negara-Negara Muslim: Problem dan Prospek,Bandung : Mizan

Mukti,H.A Ali. 1993. Alam Pikiran Islam Modern di India dan Pakistan, Bandung : MIZAN 2005. Library of Congress-Federal Research divission : Pakistan, Februari

Mahmood, Tahir. 1972. Family Law Reform in the Muslim World. (New Delhi : The Indian Law Institute

Mardani. 2011. Hukum Perkawinan Islam di Dunia Islam Modern,Yogyakarta: Graha Ilmu

Musahadi HAM. 2009. Continuity And ChangeReformasi Hukum Islam : Belajar Pada Pemikiran Muhammad Iqbal dan Fazlur Rahman, (emarang : Walisongo Press

Mustofa dan Abdul Wahid. 2009 .Hukum Islam Kontemporer,Jakarta : Sinar Grafika

Muzdhar, Atho' dan Khairuddin Nasution. 2003. Hukum Keluarga di Dunia Islam Modern : Studi Perbandingan dan Keberanjakan UU Modern dari Kitab-Kitab/fiqih, Jakarta : Ciputat Press

Shaikh,Barrister Ali. Artikel, Law Divorce and Khula in Pakistan 
Yatim, Badri. 2004. Ensiklopedia Islam,Jakarta: Ichtiar Baru Van Hoeve

\section{Website}

http://Pakistanconstitutionlaw.com diakses pada tanggal 28 september 2014

Kuna, Makalah, Perceraian dalam Perundang-Undangan Pakistan (Telaah Kritis Terhadap Undang-Undang Perceraian 1939 dan MFLO 1961)http://kursiana2811.blogspot.com. Diakses pada tanggal 26 september 2014

http://muslimdaily.net, diakses pada tanggal 28 september 2014

http://batampos.co.id. Laporan oleh Mudassar Shah 6 Maret 2013, artikel ini pertama kali disiarkan pada program berita Asia caling www.Asiacalling.org, diakses pada tanggal 28 September 2014 